\title{
METAMORPHOSED AND DEFORMED PILLOWS FROM LOSOMÄKI: EVIDENCE OF SUB-AQUEOUS VOLCANISM IN THE OUTOKUMPU ASSOCIATION, EASTERN FINLAND
}

\author{
ADRIAN F. PARK and D. R. BOWES
}

\begin{abstract}
PARK, A. F. and BOWES, D. R. 1981: Metamorphosed and deformed pillows from Losomäki: evidence of sub-aqueous volcanism in the Outokumpu association, eastern Finland. Bull. Geol. Soc. Finland $53-2,135-145$.
\end{abstract}

\begin{abstract}
Pillow lavas, some highly deformed and now seen as banded diopside amphibolites and tremolite-epidote-chlorite rocks (»barren skarn»), occur within the lower Proterozoic Outokumpu rock association at Losomäki, $50 \mathrm{~km} \mathrm{N.W.} \mathrm{of} \mathrm{Outokumpu.} \mathrm{The} \mathrm{occurrence} \mathrm{of} \mathrm{these}$ sub-aqueous volcanic assemblages, together with the previously described serpentinite-metadolomite-non-detrital quartzite-cupriferous sulphide ore-black schist assemblage, is similar to those found in both Phanerozoic ophiolite complexes and the lower members of Archaean greenstone belts. The nature of this assemblage is of significance in assessing the lithospheric processes operative in early Proterozoic times as well as in elucidating the evolution of the Svecokarelides.

Park, Adrian F. and Bowes, D. R., Department of Geology, University of Glasgow, Glasgow G12 8QQ, Scotland.
\end{abstract}

\section{Introduction}

The mafic pillow-lava - serpentinised ultramafic plutonic rock association is an integral part of both the lower members of Archaean greenstone terranes and Phanerozoic ophiolite complexes. In both instances, the association is a significant indicator of lithospheric processes. Although the mechanisms operative in the development of Archaean greenstone belts are the subject of much debate, in the case of ophiolite suites much light has been thrown on processes operative in the past by comparison with present day plate tectonic processes. How far back in geological time this comparison is valid has yet to be conclusively established.

Besides pillow-lavas of broadly oceanic provenance and ultramafic material of a primitive nature, both the lower members of Archaean greenstone belts and ophiolite com- plexes include carbonaceous pelites, dolomites and siliceous chemical sediments as integral parts. In addition sulphide ore deposits, particularly of cupriferous pyrite and pyrrhotite, are associated with the volcanic members of both associations.

The lower Proterozoic Outokumpu association in the Svecokarelides of eastern Finland (Gaál et al., 1975) contains most of the rock types of these associations, viz. serpentinite, metadolomite and non-detrital quartzite together with black schist (Huhma, 1975). In addition there are copper deposits of major economic importance (Outokumpu, Vuonos, Luikonlahti, see Fig. 1) for which a marine environment of formation is indicated by sulphur isotope studies (Mäkelä, 1974). This is consistent with a volcanogenic exhalative origin first suggested by Bochert (1954). However, to date no direct observational evidence indicating the existence of volcanic products 


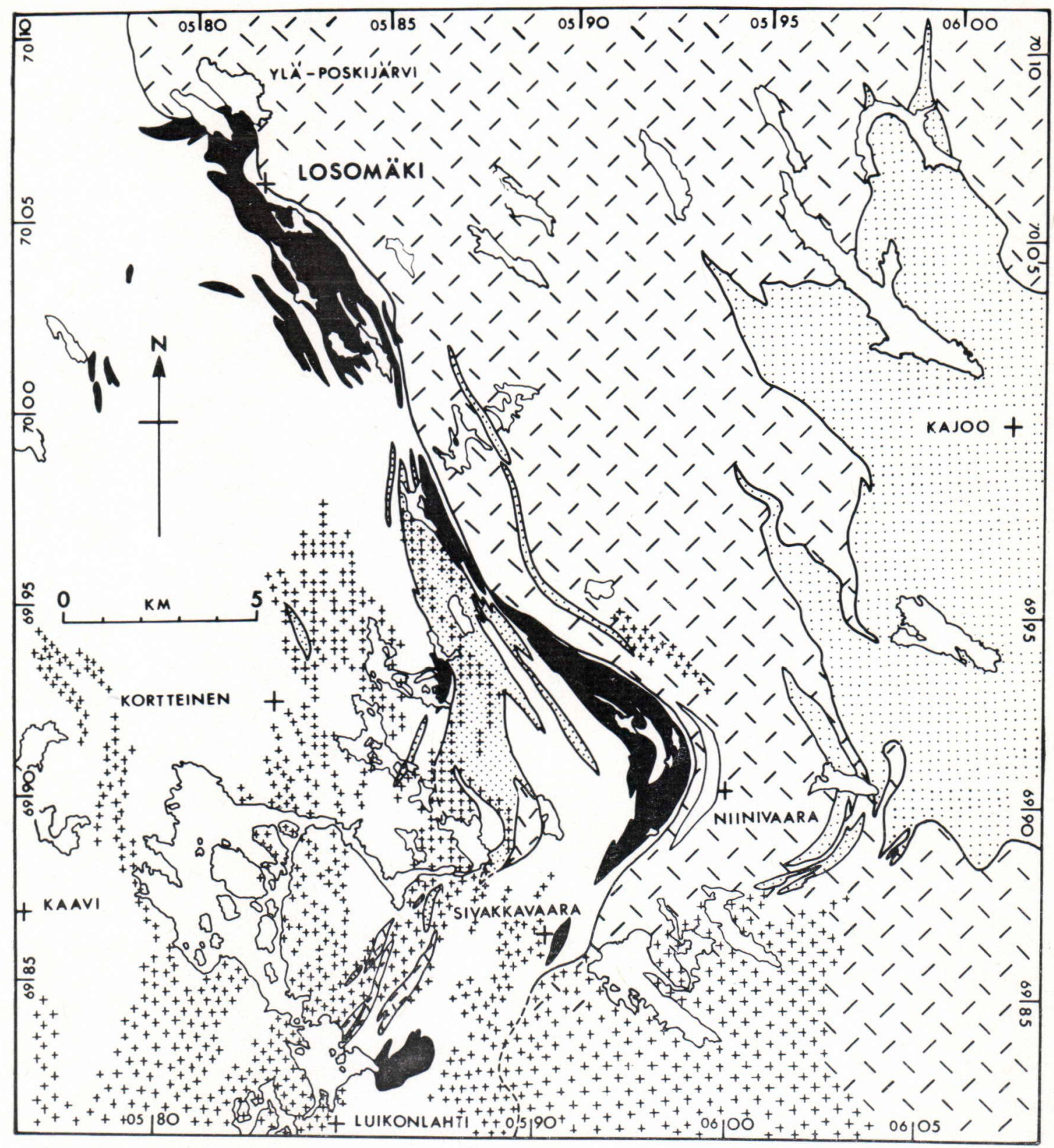

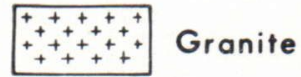

Mica schists

(Kalevian)

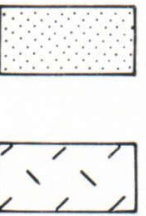

Meta-arenites, quartzites.

mica schists, amphibolifes.

(Jafulian)

Quarłzofeldspathic gneiss

(Presvecokarelian)

Serpentinites, metavolcanic rocks,

metasediments (Outokumpu association) 
in the Outokumpu association has been recorded. Several authors have suggested a volcanic (and ophiolitic) origin of the association, notably Wegman (1928) who based his conclusions on analogies between the Karelian mica schist (meta-flysch)-serpentinite association and the flysch-ophiolite assemblage of the Alps. Despite more recent stratigraphic studies having indicated that many of Wegman's conclusions are untenable, the volcanicophiolite implication has survived. For example, Huhma (1975, p. 139) refers to the Vuonos $\mathrm{Cu}-\mathrm{Co}-\mathrm{Ni}$ deposit as being within »a basin (that) contains serpentinite ophiolites».

A major difficulty relating to the recognition of original features of rocks of the Outokumpu association derives from the intense deformation and high-grade metamorphism they have suffered during an extensive polyphase deformational and polymetamorphic history (cf. Gaál et al., 1975). However, in some high-grade terranes not unlike the Svecokarelides of eastern Finland, volcanic products showing varying degrees of deformation and metamorphism have been recognized and banded rocks derived from pillow basalts have been described (cf. Myers, 1978). In southern Finland, in the Svecokarelides, Ehlers (1978) has shown that banded diopside-bearing amphibolites and banded amphibole-bearing gneisses were derived from volcanic rocks, including pillow lavas (cf. Gaál, 1980). Rocks which have corresponding mineralogical compositions also occur in the Outokumpu association, in particular the banded or massive diopside-tremolite-epidote rock, known locally as »barren skarn» and included within the lithological units designated as "skarn» on the maps of the Outokumpu district (Huhma, 1975). The strong

Fig. 1. Outline geological map of part of eastern Finland showing the distribution of the rocks of the Outokumpu asisociation. banding of some of the rocks is a product of intense tectonism associated with metamorphic differentiation. However, in the Losomäki area, about $50 \mathrm{~km}$ northwest of Outokumpu (Fig. 1), banded amphibole- and pyroxene-bearing rocks grade into rocks showing features which pre-date the earliest deformational fabric and which can be identified as pillow structures (Figs 2, 3, 4). These observations show that the Outokumpu association does contain one major lithology of an ophiolite complex not previously identified positively. They also mean that criteria can be established by which features consistent with a volcanic parentage can be identified in at least some, and possibly many, of the banded mafic rocks of the district, features that would have remained unrecognized had the gradation from clearly identifiable pillow lavas to banded mafic rocks not been observed.

\section{Structural setting}

The rocks of the Outokumpu association in the Losomäki area occur within a major zone of thrusts, with imbricate zones, in which the rocks of the association, or parts of the association, have been repeated in a stack of tectonic slices which include slices of Archaean basement gneisses, Kalevian mica schists and Jatulian quartzites and amphibolites (cf. Gaál et al. 1975 for regional geological setting). The thrusts are expressions of the second deformational phase $\left(D_{2}\right)$ of the Svecokarelian orogenic episode of eastern Finland (cf. Bowes, 1976 a). Adjacent to and within the thrust zones, high strain has resulted in the production of an intense schistosity $\left(\mathrm{S}_{2}\right)$, but within the more central parts of individual tectonic slices, earlier fabrics and features are preserved. The $\mathrm{S}_{1}$ surfaces developed during the first deformational phase are generally very prominent, these 
being expressed as a foliation related to metamorphic segregation formed under upper amphibolite facies conditions (cf. Hopgood, 1980, fig. 16). It is seen to overgrow original features such as bedding and pillows. Later structural elements deform or cut the $D_{1}$ and $\mathrm{D}_{2}$ features as well as original structures. They include locally developed drag-folds (in places conjugate structures and referred to as $\left.\mathrm{F}_{2 \mathrm{c}}\right)$ with an associated cleavage $\left(\mathrm{S}_{2 \mathrm{c}}\right)$, the major folds at Losomäki $\left(\mathrm{F}_{3}\right)$ with their axial planar cleavage $\left(\mathrm{S}_{3}\right)$ and an $\mathrm{S}_{4}$ fracture cleavage whose expression is lithologically dependent.

The fabrics seen in the rocks of Losomäki have regional expression in eastern Finland where they characterise the cover sequence of the Svecokarelides. The $F_{1}$ folds are generally isoclinal with the axial planar $S_{1}$ fabric (initially a spaced pressure solution cleavage, recrystallized as a differential mineral growth) nearly flat-lying. Early $D_{1}$ movements resulted in the emplacement of a major thrust-bound nappe unit (the SavoKarjalan nappe) whose base is defined by the occurrence of the Outokumpu association. $M_{1}$ metamorphism (garnet-cordierite sub-division of the upper amphibolite facies) reached a peak after the $D_{1}$ nappe emplacement whose effect was to repeat the stratigraphic succession without inversion. $\mathrm{F}_{2}$ folds are tight to open, commonly asymmetrical and the related prominent schistosity is usually manifest as a biotite growth. Transposition is generally marked within the $\mathrm{S}_{2}$ fabric, especially in some mica schists, and in thrust zones, in which earlier-formed structures are almost completely obliterated. $\mathrm{M}_{2}$ metamorphism was also at upper amphibolite facies (garnet-cordierite). After $\mathrm{M}_{2}$ the $\mathrm{P}-\mathrm{T}$ conditions corresponded to those of greenschist facies. Though regionally penetrative, $\mathrm{S}_{2 \mathrm{c}}, \mathrm{S}_{3}$ and $\mathrm{S}_{4}$ overgrow rather than replace earlier fabrics. The $\mathrm{F}_{2 \mathrm{c}}$ folds tend to be concentrated in NW-SE-trending belts parallel to the major (transcurrent) Raahe-Ladoga lineament (N. M. Halden, T. J. Koistinen, pers. comm.). $\quad \mathrm{F}_{3}$ folds are open and upright with approximately $\mathrm{N}-\mathrm{S}$-striking axial planes and near horizontal axes. $\mathrm{F}_{4}$ folds are also often upright with axes mainly plunging at shallow angles to the southwest (cf. Bowes, 1976 a).

The recognition of these various tectonic and metamorphic features is critical in the reconstruction of the original shapes and lithological variations of the volcanic features (cf. Figs 2, 3, 4). In addition their identification as parts of regionally expressed features of the early Proterozoic Svecokarelides, rather than of the late Archaean Presvecokarelides (Bowes, $1976 \mathrm{~b}, 1980 \mathrm{a}$ ) excludes the possibility of the volcanic features being those of a greenstone belt in tectonic slices of basement.

\section{Description of pillows}

The pillow-bearing assemblage of Losomäki consists of diopside-epidote pods (largely zoisite and $\alpha$-zoisite, with epidote) in a host of tremolite-chlorite schist. In the two tectonic slices of the $\mathrm{D}_{2}$ imbricate stack south of Ylä-Poskijärvi (Grid ref. 817 082) in the Losomäki area, they are intercalated with quartz rock, various skarns and black schists. In the central part of one tectonic slice, over 30 metres from a $\mathrm{D}_{2}$ thrust, the pod-like masses representing pillows are elongate to varying degrees and an $\mathrm{S}_{1}$ banded fabric runs through them (Fig. 2). Some of the pods, notably those showing least elongation, show marked variation in grain size from the centre to the margin with a texture strongly resembling ophitic texture seen on the weathered surfaces of some of the central parts. The rim, which completely encloses the cores of those pillows not affected by boudinage, is interpreted as a quench product.

The pillows show progressive flattening within the $\mathrm{S}_{1}$ fabric. Some also show the 

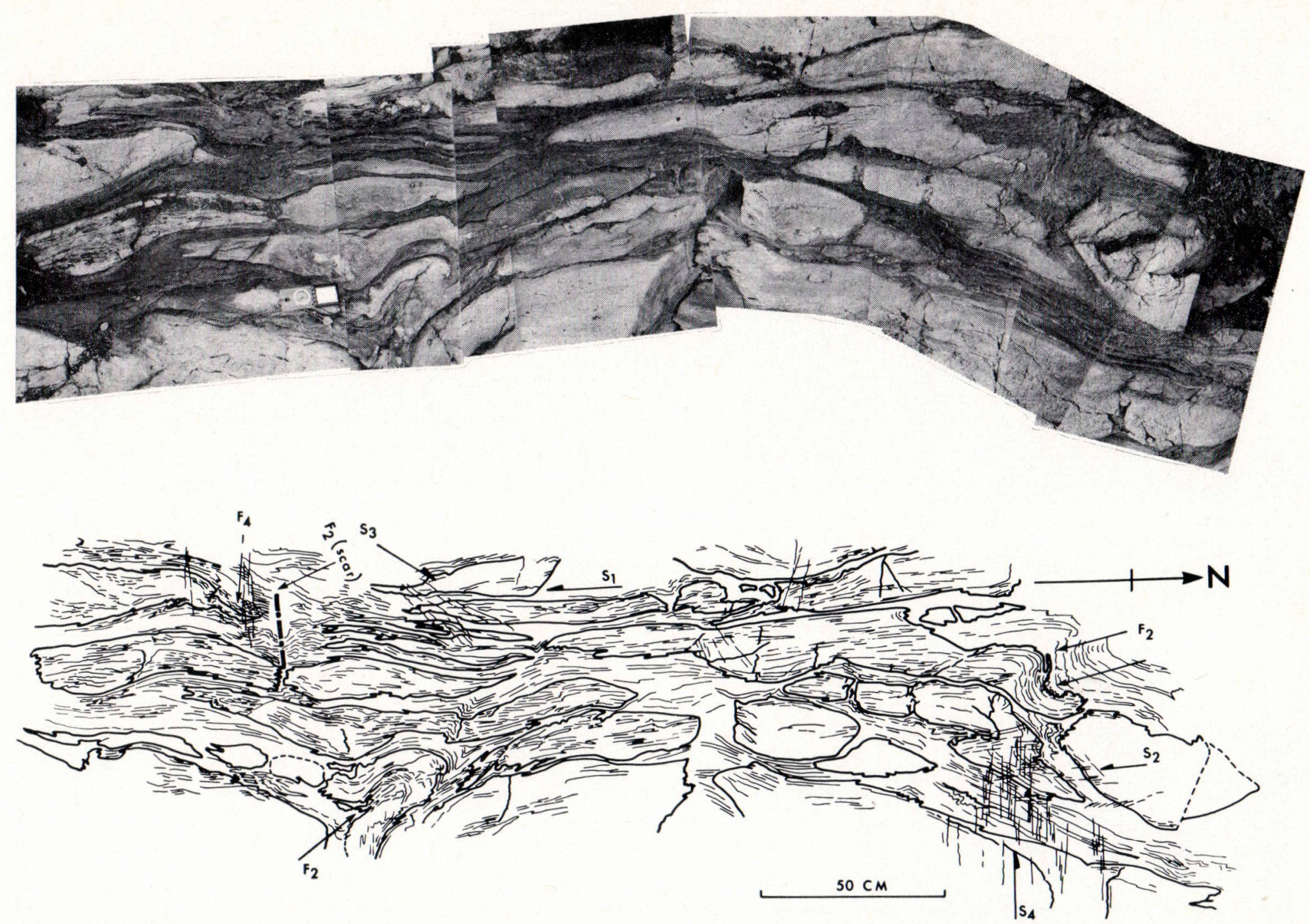

Fig. 2. Photomosaic and diagram of deformed pillows (diopside-plagioclase-zoisite) in matrix of tremolite-chlorite schist; Ylä-Poskijärvi, Losomäki (Grid ref: 812081 ). 

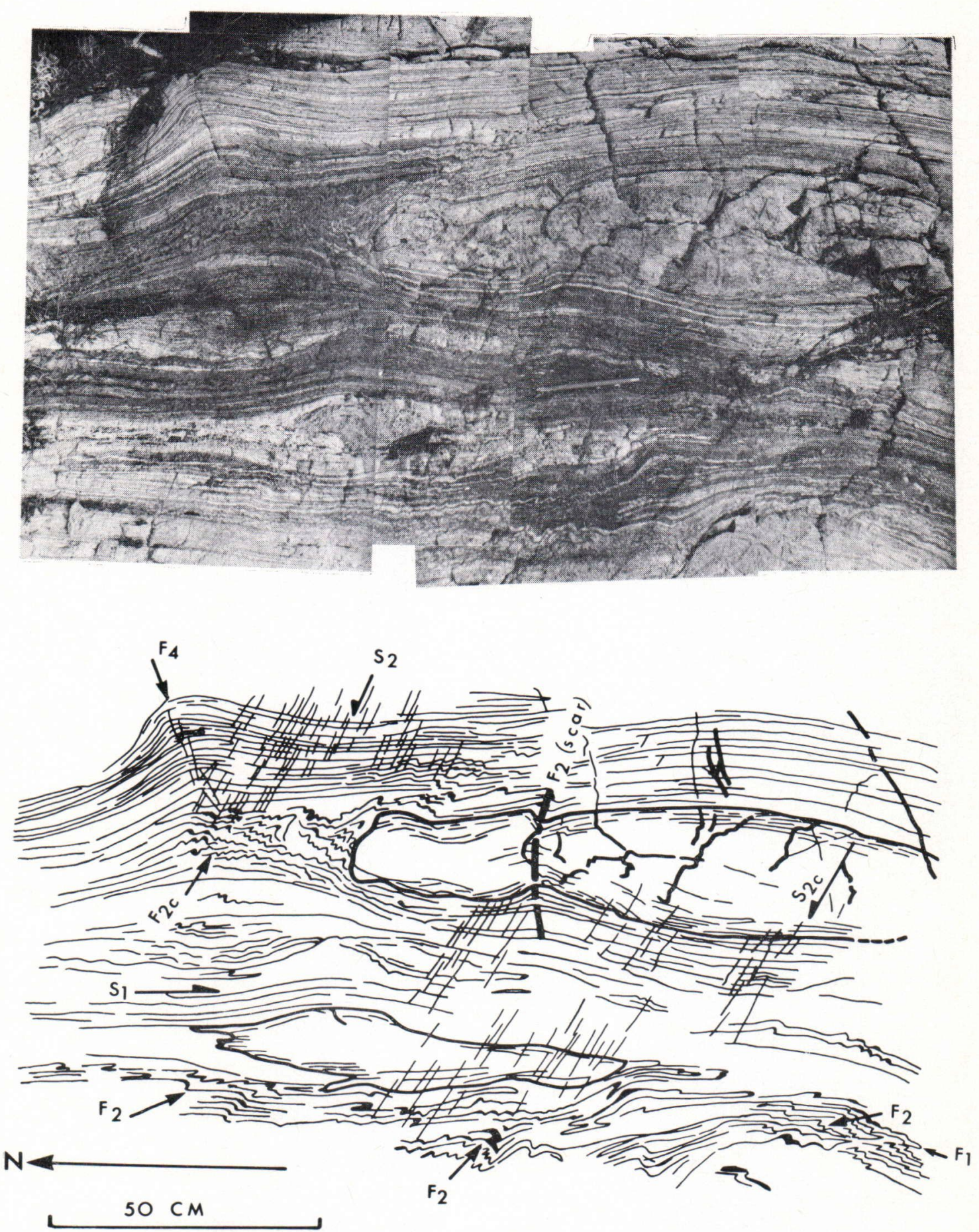

Fig. 3. Photomosaic and diagram of deformed pillows (diopside-zoisite) in matrix of banded tremolitechlorite schist; Ylä-Poskijärvi, Losomäki (Grid ref: 813 082); overlap with Figure 4 at right hand side. 

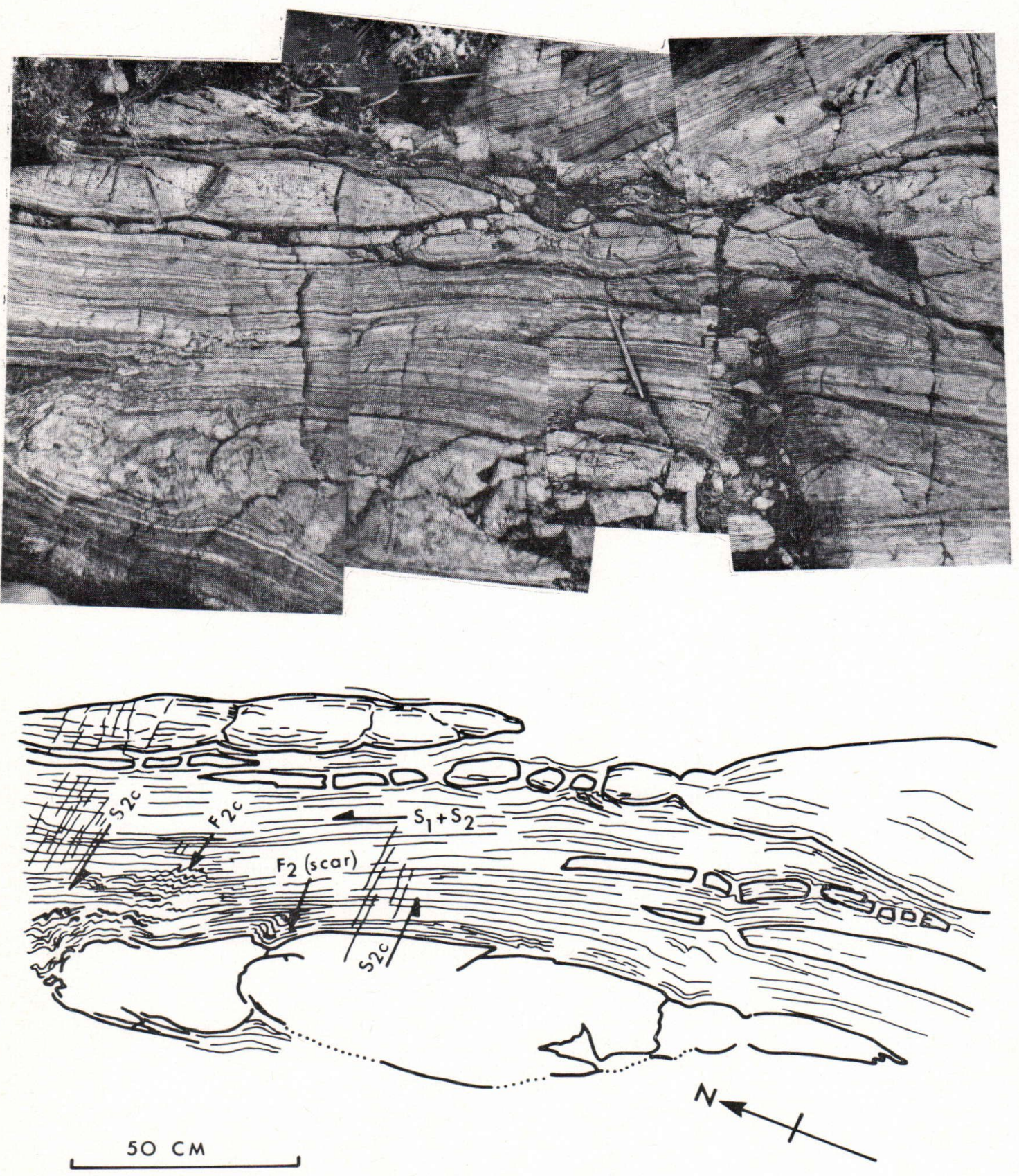

Fig. 4. Photomosaic and diagram of deformed pillows; overlap with Figure 3 at left hand side. 
beginnings of fragmentation by boudinage induced by the competence contrast between pillow and matrix; these morphological effects can be distinguished from those related to original shape (Fig. 5). In the matrix $F_{1}$ folds are isoclinal. They, together with elongate pillows, are refolded by $\mathrm{F}_{2}$ asymmetrical folds. The associated axial planar $S_{2}$ cuts $S_{1}$ at a shallow angle. It is mainly expressed in the matrix material between the pillows, but occasionally is expressed in the pillows themselves. Deformation of $\mathrm{S}_{1}$ by $\mathrm{F}_{2}$ scar folds at boudin necks indicates that the major boudinage is a $\mathrm{D}_{2}$ feature related to extension in $\mathrm{F}_{2}$ limbs.

Removal of the effects of $\mathrm{D}_{1}$ and $\mathrm{D}_{2}$ leaves concentrically zoned (fine- - coarse-grained) pods in a chloritic matrix (Fig. 5). The matrix differs so markedly from the pods that its phyllonitic derivation from the pods must be discounted. An origin of the pods as the result of pre- $\mathrm{D}_{1}$ boudinage can also be discounted because (1) the marginal zones completely surround the cores and (2) the pods themselves do not show a distribution consistent with the fragmentation of an earlier layered sequence.

While the principle fabric of the rocks in Figure 2 is $\mathrm{S}_{1}$, that in Figures 3 and 4 is $\mathrm{S}_{2}$. The rocks illustrated in the two later figures are within five metres of a $D_{2}$ thrust with $\mathrm{F}_{2}$ folds isoclinal and virtually co-axial planar with the $\mathrm{F}_{1}$ folds. Remnants of large pillows are preserved but boudinage is more strongly developed than in the rocks of Figure 2. The large pod near the centre of Figure 3 has a coarse grained core, which is without strong macroscopic foliation, but the marginal zone shows a strong planar fabric which at boudin necks ( $F_{2}$ scar folds) is deformed, but elsewhere (Fig. 3 top left) is a composite $\mathrm{S}_{2}$ and $\mathrm{S}_{1}$. Open asymmetrical $\mathrm{F}_{2 \mathrm{c}}$ folds with an axial planar cleavage deform the composite $S_{2}-S_{1}$ fabric.
The change in intensity of expression of $\mathrm{D}_{2}$ is parallelled by the degree of elongation exhibited by the pillows; the elongation ratio changes from 2 to $5: 1$ in Figure 2, to 10 to 20:1 in Figure 4. With the exception of the large example common to Figures 3 and 4 , the pillows are represented as elongate boudin trails, but their original nature is indicated by their fine grained sheaths. Adjacent to $D_{2}$ thrusts, the composite $S_{1}-S_{2}$ is so penetrative and closely spaced that intrafolial features are almost completely obliterated (Fig. 3 top left, Fig. 4 centre left). It is such banded rocks as these that are commonly seen in the outcrops of the »barren skarns» of the district. Away from the $\mathrm{D}_{2}$ thrust planes, and within tectonic slices, the metavolcanic rocks are in original rather than tectonic contact with other lithologies more typical of the Outokumpu association, e.g. quartz-rock and chrome-tremolite-carbonate skarn.

\section{Discussion}

Criteria for the recognition of rocks derived from pillow-bearing assemblages in the Outokumpu association, and their separation from rocks with pod-shaped masses resulting wholly from boundinage, can now be established (Fig. 5).

1. Pillows exhibit some degree of concentricity in zoning from coarse- to fine-grain size. This zoning can be recognized even where there has been a considerable degree of flattening and recrystallization leading to the development of a penetrative $\mathrm{S}_{1}-\mathrm{S}_{2}$ schistosity.

2. Pillow terminations exhibit folding of both the outer sheath and the foliations, as opposed to only the former in boudin-neck scar-folds.

3. The central parts of some pillows exhibit igneous textures. 


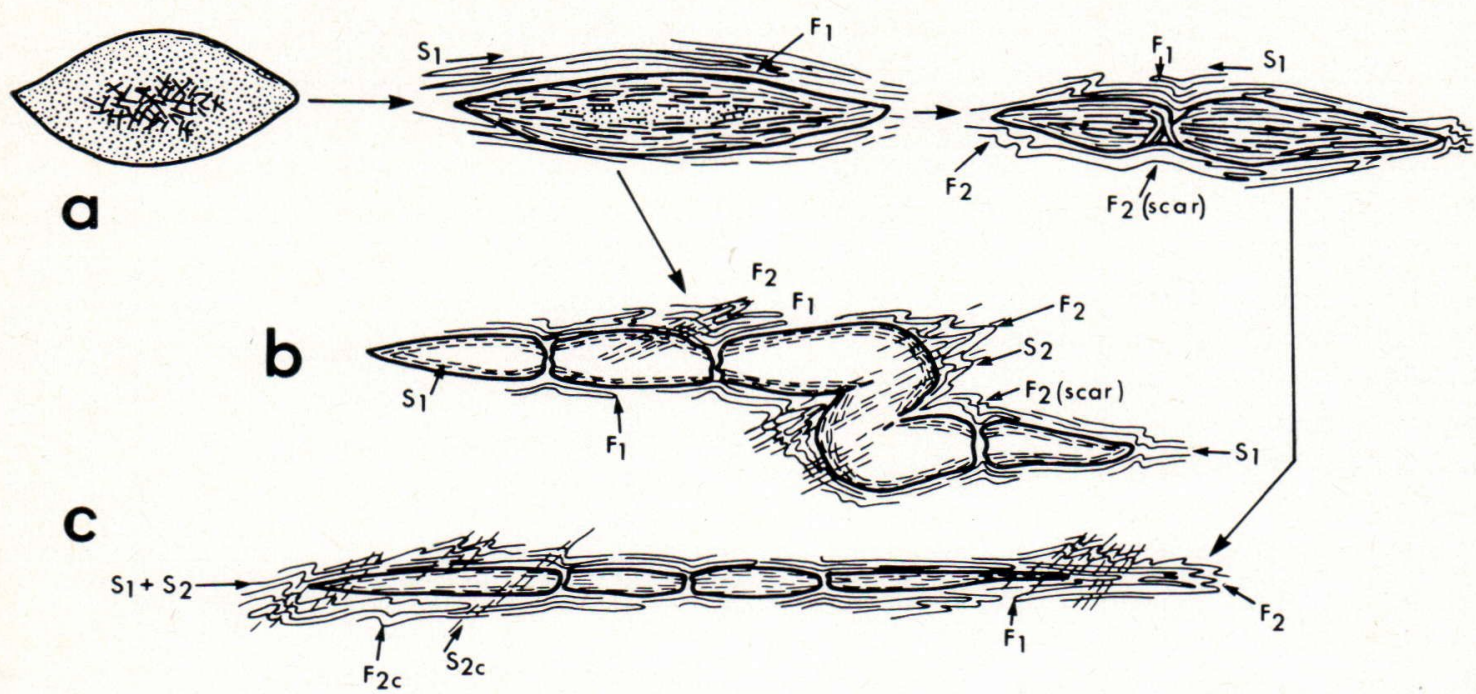

Fig. 5. Schematic representation of pillows and their progressive deformation. (a) Flattening in $D_{1}$ and boudinage in $\mathrm{D}_{2}$; away from $\mathrm{D}_{2}$ thrusts. (b) Flattening in $\mathrm{D}_{1}$ and folding and boudinage in $\mathrm{D}_{2}$; away from $D_{2}$ thrusts. (c) Flattening in $D_{1}$ and $D_{2}$, boudinage in $D_{2}$, folding in $D_{2 c}$; adjacent to $D_{2}$ thrust.

The demonstration of the existence of pillows means that part of the Outokumpu association resulted from sub-aqueous volcanism. The products are notably free from chromium-bearing silicate minerals, such as chrome-diopside, chrome-tremolite, chromeepidote and uvarovite, which characterize skarn rocks with which these metavolcanic rocks have previously been grouped.

Discrimination of the metavolcanic rocks in the Outokumpu association from those of both the lower Proterozoic Jatulian assemblage and the upper Archaean greenstone assemblage is based mainly on structural grounds. The Jatulian rocks of the Losomäki district belong to different structural units than those of the Outokumpu association (autochthonous and allocthonous sequences, respectively). Accordingly, to have Jatulian and Outokumpu assemblages juxtaposed would require tectonic contacts. However, at Losomäki volcanic rocks have original, non-tectonised contacts with other units of the Outokumpu association. Comparable structural arguments apply to excluding the presence of metavolcanic rocks of the Presvecokarelian greenstone belts amongst the Outokumpu association. In addition, there are no fabrics earlier that the $D_{1}$ Svecokarelian fabrics in the metavolcanic rocks of Losomäki, while slices of Presvecokarelian basement would be expected to show extensive effects of late Archaean polyphase deformation as well as the effects of early Proterozoic processes (cf. Bowes, 1980 a). Also, those basement slices that have been emplaced into the cover assemblage of the Svecokarelides are composed dominantly of quartzofeldspathic gneisses and a related granitoid association and not the rock types known from the late Archaean greenstone belts of eastern and northern Finland (Blais et al., 1977; Gaál et al., 1978).

Banded diopside amphibolites and diopsidetremolite-epidote rocks like those in which the pillows occur at Losomäki are a common feature of the »barren skarns» throughout the area in which the Outokumpu association is known. This suggests that the volcanic 
assemblage could be widespread. Its recognition in a strongly tectonised state could be based on the determination of the geochemical characters of the Losomäki pillow lavas as indicative of the composition of the metavolcanic assemblage. In this regard it should be noted that Huhma and Huhma (1970) recorded that some of the chloritic schists of the Outokumpu district differed markedly in geochemical character from those which were clearly derived by tectonisation of ultramafic rocks.

The recognition of the existence of subaqueous volcanic rocks amongst the Outokumpu association, whose other members have been assumed by a number of workers to have been indirect products of volcanic processes, clears up a major anomaly. It also opens up the possibilities of (1) chemical composition being used to establish possible conditions and depth of the mantle source region for the basic magma and hence geotectonic position, (2) the Outokumpu association being a major factor in unravelling the evolution of the Svecokarelides (Campbell, 1978; Bowes, $1980 \mathrm{~b}$ ), and (3) the Outokumpu association being used both to establish the nature of early Proterozoic lithospheric development and also to assess similarities and differences in Archaean, Proterozoic and Phanerozoic mafic-ultramafic rock associations. Furthermore, not only does the recognition of pillowlavas provide a recognized source for cupriferous deposits formed in an oceanic environment (cf. Bochert, 1954; Mäkelä, 1974), but also it places the Outokumpu association and its ores in a more rigorously defined paragenetic setting. This has implications for the understanding, assessment and further exploration of this particular ore province.

Acknowledgements - Thanks are expressed to Fredrik Björnberg of Myllykoski Oy, for permission to publish material dealing with the Losomäki area, to Kurt Karlsson and Tapio Salaterä of Malminetsintä, Luikonlahti mine who introduced one of us (AFP) to the rocks of the Losomäki area, to the staff of Malminetsintä, Outokumpu Oy (particularly Tapio Koistinen) for their help during fieldwork in Finland, and to D. S. Campbell and A. M. Hopgood for using their experience of comparable rocks elsewhere to support our field observations and interpretations. A grant to one of us (AFP), from the Natural Environment Research Council of Great Britain is gratefully acknowledged.

\section{References}

Blais, S., Auvray, B., Bertrand, J.-M., Capdevila, R., Hameurt, J., and Vidal, Ph. (1977) Les grands trait géologiques de la ceinture archéenne de roches vertes de SuomussalmiKuhmo (Finlande orientale). Bull. Soc. Géol. France 19, 1033-1039.

Bochert, H. (1954) Kritische Bemerkungen zu zwei neuen Arbeiten über Outokumpu, Finnland. Zeitschr. Erzberg. Metall. 7, 82-84.

Bowes, D. R. (1976 a) Tectonics of the Baltic Shield in the period, 2,000-1,500 million years ago. Acta Geol. Polon. 26, 355-376.

- (1976 b) Archaean crustal history in the Baltic Shield. In: Windley, B. F. (ed.) The Early History of the Earth. Wiley, London, 481-488.

- (1980 a) Structural sequence in the gneissose complex of eastern Finland as a basis for correlation in the Presvecokarelides. Acta Geol. Polon. 30, 15-26.

- $(1980 \mathrm{~b})$ Correlation in the Svecokarelides and a crustal model. In: Mitrofanov. F. P. (ed.) Principles and criteria of sub-division of Precambrian in mobile belts. Nauka, Moscow, $294-303$

Campbell, D. S. (1978) Structural and metamorphic studies in the Svecokarelides, Tampere, Finland. Unpubl. Ph.D. thesis, Univ. of Glasgow. Ehlers, C. (1978) Gravity tectonics and folding around a basic volcanic centre in the Kumlinge area, S.W. Finland. Bull. Geol. Surv. Finland 295, $43 \mathrm{pp}$.

Gaál, G. (1980) Geological setting and intrusion tectonics of the Kotalahti nickel-copper deposit, Finland. Bull. Geol. Soc. Finland 52, 101-128. 
- , Koistinen, T. and Mattila, E. (1975) Tectonics and stratigraphy of the vicinity of Outokumpu, North Karelia, Finland. Bull. Geol. Surv. Finland 271, 67pp.

- , Mikkola, A. and Söderholm, B. (1978) Evolution of the Archaean crust in Finland. Precambrian Res. 6, 199-215.

Hopgood, A. M. (1980) Polyphase fold analysis of gneisses and migmatites. Trans. R. Soc. Edinb. Earth Sci. 71, 55-78.

Huhma, A. (1975) Precambrian rocks of the Outokumpu, Polvijärvi, and Sivakkavaara mapsheets. $1: 100,000$. Geologinen Tutkimuslaitos Espoo. 131 pp.

- , and Huhma, M. (1970) Contributions to the geology and geochemistry of the Outokumpu region. Pt. II. Ni, Co and $\mathrm{Cu}$ in some rocks of the Outokumpu region. Bull. Geol. Soc. Finland $42,67-87$.

Myers, J. S. (1978) Formation of banded gneisses by deformation of igneous rocks. Precambrian Res. 6, 43-64.

Mäkelä, M. (1974) A study of sulphur isotopes in the Outokumpu ore deposit. Bull. Geol. Surv. Finland 267, 45 pp.

Wegman, C. E. (1928) Über die Tektonik der jüngeren Faltung in Ostfinnland. Fennia 50 (16), 1-22.

Manuscript received, July 27, 1981 